\title{
PENYULUHAN PROGRAM POKOK TANAM TOGA MAHASISWA KKN-PPM UNIVERSITAS PGRI ADI BUANA SURABAYA DI DESA BULANG PRAMBON SIDOARJO
}

\author{
Erlin Ladyawati ${ }^{1}$, Verawati ${ }^{2}$, Laili Rohmawati ${ }^{3}$, Kiki Mirna Sari ${ }^{4}$, Serlia Bawan ${ }^{5}$, Husnul Mufidah $^{6}$, \\ Jakfar Iskandar Ramlan ${ }^{7}$, Gita Anjany ${ }^{8}$, Arif Tri Yulianto ${ }^{9}$ \\ 1,2,3,4,5,6,7,8,9 Fakultas Keguruan dan Ilmu Pendidikan, Universitas PGRI Adi Buana Surabaya \\ Email: ${ }^{1}$ erlin@ unipasby.ac.id, ${ }^{2}$ verawati03062012@gmail.com
}

\begin{abstract}
Toga is an important thing to be aplication. Toga is a plant that has particularly many functions or can be meant by multi-purpose plants that can be applied in a household or community. Garden utilize unused for planting toga is a useful thing to do. TOGA (Plant Medicine Family) is a good thing to do, especially to improve the quality of health of people who use it as a plant gardener plants medicine family. Utilizing the plant medicine family of a good thing at the same time benefit from simple things become things much beneficial for conservationists or growers plant medicine family. Finally, many familys growed plant medicine family in the his house with many fariety plant medicine family, example jahe plant, kencur plant, onion plant, garlic plant and etc. So, we as a big family KKN-PPM University PGRI Adi Buana feels appriciate to people in the BulangPrambon.
\end{abstract}

Keywords : TOGA, growed, and aplication

\section{PENDAHULUAN}

Kuliah Kerja Nyata Pemberdayaan Masyarakat (KKN-PPM) adalah suatu program kegiatan yang harus dilaksanakan oleh mahasiswa sesuai dengan kurikulum di universitas PGRI Adi Buana Surabaya yang merupakan implementasi dari peraturan Pemerintah Republik Indonesia No.60 tahun 1999 tentang pendidikan tinggi. KKN-PPM merupakan bentuk pengalaman ilmu pengetahuan teknologi dan seni dalam upaya memecahkan permasalahan serta menanggulangi secara pragmatis. Dengan kata lain KKN-PPM membantu dan memotivasi masyarakat dengan melaksanakan pengalaman ilmu pengetahuan teknologi bagi warga desa yang disinggahi oleh mahasiswa.

Desa merupakan kesatuan masyarakat hukum yang mempunyai susunan asli berdasarkan hak asal usul bersifat istimewa, memiliki keanekaragaman, partisipasi, otonomi asli, demokratisasi asli dan pemberdayaan masyarakat (Widjaja,2003 dalam Atnuri:32) Dalam penyelenggaraan oemerintah di desa dan BPD harus harus sejalan seiring sekata.
Kekrteatifan dimulai dari kelompok desa yang maju dan mengerti cara pemanfaatan hal yang paling sederhana dan dapat dibuat suatu yang menarik atau menghasilkan sesuatu yang bermanfaat dan dapat dimanfaatkan terutama oleh masyarakat desa.

Tanam toga merupakan suatu hal yang biasa dilakukan didalam kelompok masyarakat desa atau kelompok pertanian yang ada di suatu desa. Tanaman obat sudah banyak sekali digunakan oleh manusia sejak zaman dahulu. Bahkan dipercaya mempunyai khasiat yang lebih ampuh daripada obat-obat dokter. Namun, karena perkembangan jaman dan semakin meningkatnya pengetahuan manusia tentang farmakologi dan ilmu kedokteran, banyak masyarakat yang beralih ke obat-obatan dokter karena lebih mempercayai obatobatan kimia yang telah teruji khasiatnya secara laboratorium, dibandingkan dengan obat tradisional yang banyak belum bisa dibuktikan secara laboratorium.

Seiring berjalannya waktu, kehidupan berubah. Dengan adanya krisis moneter, masyarakat terdorong kembali menggunakan obat-obat tradisional yang boleh dikatakan 
bebas dari komponen impor, terutama bebas dari bahan-bahan kimia yang kemungkinan dapat berakibat fatal bagi kesehatan tubuh. Karena dengan perkembangan teknologi pula, semakin banyak tanaman obat tradisional yang telah bisa dibuktikan khasiatnya secara laboratorium dan dijamin aman untuk dikonsumsi dan bisa menyembuhkan penyakit tanpa menimbulkan efek samping. Banyak bagian tumbuhan yang bisa digunakan sebagai obat, diantaranya adalah bagian buah, batang, daun, dan akar atau umbi. Oleh karena pentingnya tanaman-tanaman obat tersebut maka perlu kita mempelajarinya dengan baik sehingga dapat berdaya guna bagi kita.

Maka dari itu menanam toga merupakan suatu hal yang biasa dilakukan di dalam kelompok masyarakat desa atau kelompok pertanian yang ada di suatu desa. Pemanfaatan toga sanggat berguna bagi suatu kelompok masyarakat baik dari segi menambah perekonomian warga dan untuk obat tradisional yang bisa dimanfaatkan oleh kelompok masyarakat terutamanya desa yang di tempati KKN-PPM Universitas PGRI Adi Buana Surabaya. Taman toga bisa berguna dan cukup menarik untuk dilaksanakan. Dalam hal penanaman toga atau pembuatan taman toga berhasil dilaksanakan di desa bulang, Kecamatan Prambon, Kabupaten Sidoarjo yang dilaksanakan oleh kelompok KKN-PPM Universitas PGRI Adi Buana Surabaya sebagai program yang dilaksanakan untuk melaksanakan tugas sekaligus memberi pengetahuan tentang pentingnya tanam toga dan cara penanamannya.

\section{METODE}

Penyuluhan ini merupakan penyuluhan dengan menggunakan metode Observasi. Menurut Nasution (dalam Sugiyono, 2012:226) menyatakan bahwa observasi adalah dasar dari semua ilmu pengetahuan. Metode observasi adalah metode yang menggunakan cara pengamatan terhadap objek yang menjadi pusat perhatian pada penelitian (Muliawan, 2014:62).

Sedangkan menurut Zainal (2013:153) observasi adalah suatu proses pengamatan dan pencatatan secara sistematis/urut, logis, objektif, dan rasional mengenai berbagai fenomena-fenomena yang ada, baik dalam situasi yang sebenarnya maupun dalam situasi buatan untuk mencapai tujuan tertentu.
Berdasarkan pengertian-pengertian yang dikemukakan oleh beberapa ahli, maka metode obsevasi ini merupakan pengamatan yang dilakukan secara langsung kepada objek yang dituju guna mendapatkan informasi atau pengetahuan untuk mencapai tujuan tertentu.

Penyuluhan ini dilaksanakan pada bulan Februari 2017. Tempat penyuluhan di desa Bulang Kecamatan Prambon Kabupaten Sidoarjo. Subjek dalam penyuluhan ini terdiri dari warga masyarakat desa Bulang Kecamatan Prambon Kabupaten Sidoarjo yaitu ibu-ibu PKK, ibu RT dan ibu RW serta masyarakat yang ikut serta dalam penyuluhan tanam toga di Balai Desa Bulang .

Subjek yang telah dipilih kemudian diberikan wawasan atau pengetahuan tentang

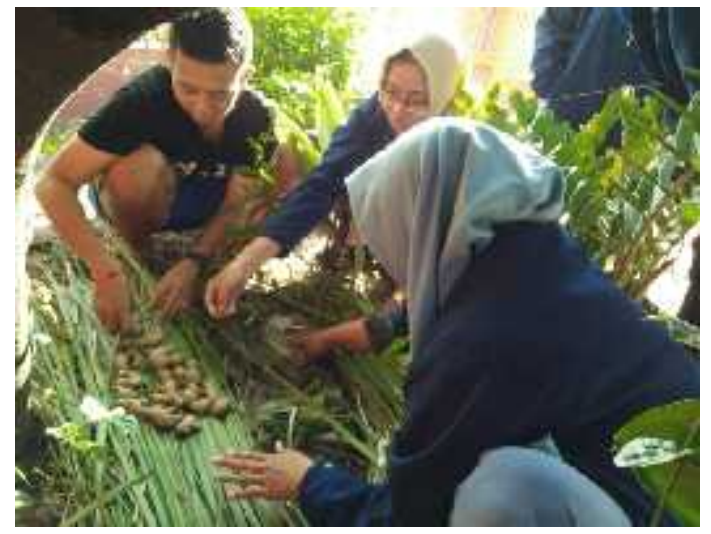

manfaat dan cara penanaman tanaman toga yang cukup mudah untuk dilakukan. Setelah melakukan penyuluhan terhadap warga desa Bulang maka semua data terkumpul, para mahasiswa melakukan reduksi untuk hasil wawancara yang telah dilakukan kemudian menyajikan data yang merupakan langkah terakhir sehingga dari hasil penyuluhan ini diperoleh simpulan.

\section{HASIL PENYULUHAN}

Hasil yang kami peroleh dari hasil penyuluhan yang dilakukan pada bulan Februari 2017 yaitu antusias para warga untuk menanam toga (tanaman obat keluarga) sangat besar yang dikarenakan adanya wawasan dan pengetahuan yang bertambah kepada para ibu yang ada di desa Bulang ini. Para warga mengetahui manfaat dari tanaman toga ini karena adanya sosialisasi yang dilakukan oleh mahasiswa KKN-PPM Universitas PGRI Adi Buana Surabaya. Tidak hanya wawasan tentang manfaat dari tanaman toga ini, tetapi para mahasiswa KKN-PPM Universitas PGRI Adi Buana Surabaya juga memberikan wawasan 
bagaimana cara menanamnya, cara pemilihan bibit yang unggul untuk ditanam, dan media apa saja yang dibutuhkan dalam penanaman tanaman toga ini.

Berikut merupakan langkah-langkah dalam penyuluhan penanaman toga yang disajikan dalam bentuk gambar.

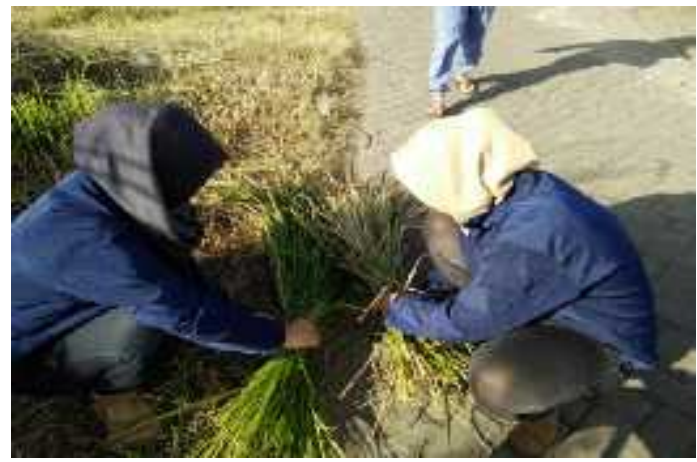

Gambar 1. Pemotongan alang-alang untuk pembibitan TOGA

Dari gambar 1 mahasiswa KKN-PPM Universitas PGRI Adi Buana Surabaya melakukan pemotongan alang-alang yang digunakan sebagai media untuk pembibitan tanaman toga.

Dari gambar 2 mahasiswa KKN-PPM Universitas PGRI Adi Buana Surabaya melakukan pembibitan tanaman obat keluarga dengan menggunakan media alangalang.

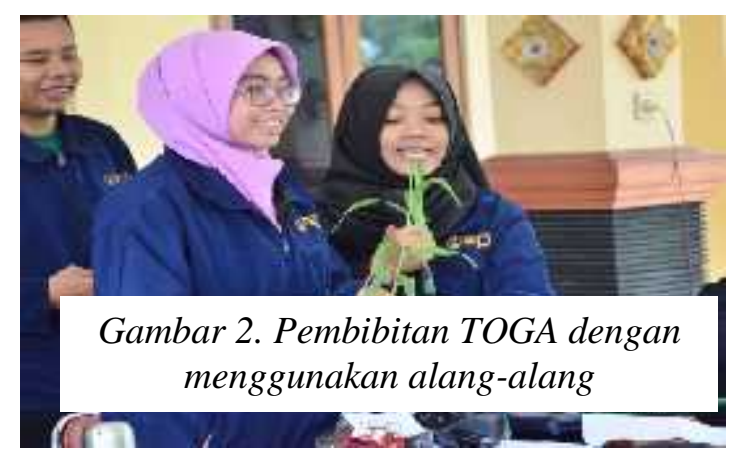

Gambar 3. Sosialisasi budidaya TOGA

Dari gambar 3 mahasiswa KKN-PPM Universitas PGRI Adi Buana Surabaya melakukan sosialisasi terhadap warga di desa Bulang.

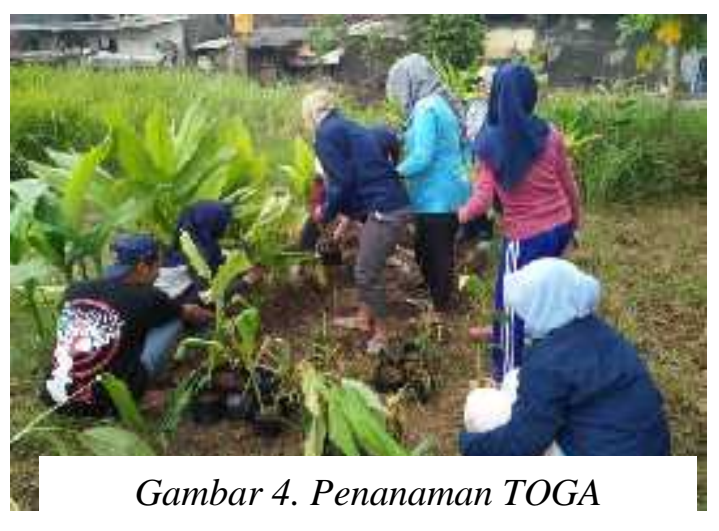

Dari gambar 4 mahasiswa KKN-PPM Universitas PGRI Adi Buana Surabaya melakukan penanaman tanaman obat keluarga yang ditanam langsung ditanah yang berada dibelakang mushollah Balai Desa Bulang.

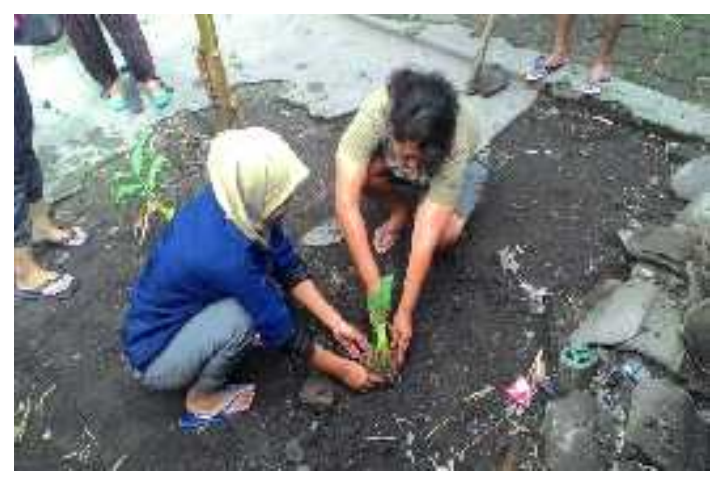

Gambar 5. Penanaman TOGA dengan warga sekitar

Dari gambar 5 mahasiswa KKN-PPM Universitas PGRI Adi Buana Surabaya melakukan penanaman tanaman obat keluarga yang ditanam langsung ditanah dengan mengajak para warga ikut serta dalam penanaman TOGA dirumahnya masingmasing.

\section{PEMBAHASAN}

Hasil penyuluhan berdasarkan kegiatan yang dilakukan dan wawancara terhadap beberapa warga desa Bulang menunjukkan bahwa penanaman tanaman obat keluarga memberikan dampak yang positif bagi masyarakat di desa Bulang tersebut. Banyak pertanyaan yang diajukan terhadap para mahasiswa KKN-PPM Universitas PGRI Adi Buana Surabaya oleh ibu-ibu PKK, ibu RT maupun ibu RW membuat para ibu-ibu yang ada didesa Bulang semakin bertambah ilmunya akan penanaman TOGA ini. Para warga juga ada yang sebagian sudah memulai menanam tanaman TOGA itu sejak setahun yang lalu. Ini membuat para mahasiswa tidak lagi mendapatkan kesulitan terhadap penyuluhan ini.

Penyuluhan tanaman toga ini juga bermanfaat bagi masyarakat yang memiliki ekonomi yang rendah. Dari hasil penanaman toga ini, warga juga menjual hasil dari penanaman toga ke pasar. Manfaat yang 
besar ini cukup dirasa baik oleh orang-orang yang menanam sendiri dirumahnya.

\section{SIMPULAN DAN SARAN}

\section{Simpulan}

Berdasarkan hasil penyuluhan dan pembahasan yang telah diperoleh maka dapat diambil kesimpulan terhadap program pokok tanam toga mahasiswa KKN-PPM Universitas PGRI Adi Buana Surabaya di desa Bulang kecamatan Prambon sebagai berikut:

1. Penanaman TOGA memberikan dampak yang positif bagi warga desa Bulang

2. Penyuluhan TOGA yang dilakukan oleh mahasiswa KKN-PPM Universitas PGRI Adi Buana Surabaya sudah dapat dikatakan berhasil untuk mengajak warga membudidayakan TOGA ini.

3. Antusias warga terhadap penanaman TOGA di desa Bulang ini sangat ramai dan banyak yang merespon setelah adanya sosialisasi di Balai Desa Bulang.

\section{Saran}

Berdasarkan pembahasan dan kesimpulan sebelumnya, maka penulis menyampaikan beberapa saran diantaranya:

a. Untuk masyarakat diharapkan untuk lebih memperdalam ilmu tentang TOGA (Tanaman Obat Keluarga) yang dirasa banyak sekali manfaat serta khasiat yang terkandung dalam TOGA ini. Selain itu, para warga diharapkan untuk menanam sendiri di pekarangan rumah masingmasing dengan terus membudidayakan tanaman obat keluarga (TOGA) ini.

b. Perlu adanya peran pemerintah desa dalam pengembangan dan penyaluran dari hasil budidaya TOGA tersebut, agar dapat meningkatkan kesejahteraan masyarakat sekitar.

c. Karena beberapa keterbatasan dalam melaksanakan penyuluhan ini, maka disarankan penyuluhan lebih lanjut dapat meningkatkan segala sesuatunya tentang pembudidayaan tanaman obat keluarga (TOGA) ini.

\section{DAFTAR PUSTAKA}

Ali, B.H., G. Blunden, M. O. Tanira dan A.
Nemmar.
2008.
Some

phytochemical,pharmacological and toxicological properties of ginger (Zingiber officinale Roscoe): A review of recent research. Food and Chemical Toxicology. 46 : 409-420

Bartley, J. dan A. Jacobs. 2000. Effects of drying on flavour compounds in Australian-grown ginger (Zingiber officinale). Journal of the Science of Food and Agriculture. 80:209-215.

Billa, A. 2016. Artikel Tanaman Toga. https://adhindabilla.blogspot.com/2016 /09/tanaman-toga-tanaman-obatobatan.html. diakses tanggal 05 Maret 2017

Kurniasari, F. 2015. Makalah Tanaman Toga. https://fentykurniasari.wordpress.com/ 2015/02/25/makalah-tanaman-toga/. Diakses tanggal 05 Maret 2017.

Sugiyono. 2012. Metode Penelitian Kuantitatif Kualitatif Dan $R \& D$. Bandung: Alfabeta.

Zainal, Arifin. 2013. Evaluasi Pembelajaran. Bandung: PT Remaja Rosdakarya. 